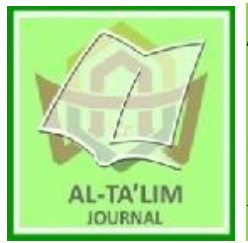

AL-TA'LIM JOURNAL, 27 (1), 2020, (103-114)

(Print ISSN 1410-7546 Online ISSN 2355-7893)

Available online at http://journal.tarbiyahiainib.ac.id/index.php/attalim

\title{
The Structure and Function of Oral Poetry Meurukon
}

Received: $19^{\text {th }}$ January 2020; Revised: $06^{\text {th }}$ February2020; Accepted: $27^{\text {th }}$ February 2020

Permalink/DOI: http://dx.doi.org/10.15548/jt.v27i1.603

\section{Mohammad Harun *)}

Universitas Syiah Kuala, Banda Aceh Indonesia.

E-mail: mohammad_harun@unsyiah.ac.id

\section{Zulfadli A. Aziz}

Universitas Syiah Kuala, Banda Aceh Indonesia.

E-mail: zulfadli.aziz@unsyiah.ac.id

\section{Azrul Rizki}

Universitas Samudra, Aceh, Indonesia.

E-mail:azrulrizki@gmail.com

\section{Saifuddin Mahmud}

Universitas Syiah Kuala, Banda Aceh Indonesia.

E-mail:saifuddinmahmud1959@gmail.com

\section{Burhansyah}

Universitas Syiah Kuala, Banda Aceh interactive-dialogical learning model.

Indonesia.

E-mail: $\underline{\text { atiburhan@yahoo.com }}$

\section{*) Corresponding Author}

Keywords: Meurukon; structure; function; Acehnese oral poetry.

How to Cite: Harun, M., Aziz, A., Rizki, A., Mahmud, S., \& Burhansyah, B. (2020). The Structure and Function of Oral Poetry Meurukon. Al-Ta lim Journal, 27(1). doi:https://doi.org/10.15548/jt.v27i1.603

\section{INTRODUCTION}

Meurukon is Acehnese oral poetry which is almost extinct. This poetry was developed on the northern coast of Aceh, covering Pidie, Pidie Jaya, Bireuen, North Aceh, Lhokseumawe, East Aceh, parts of Aceh Besar, Banda Aceh, and Langsa. The word Meurukon is originally derived from the basic word rukon (Arabic: rukn) which means harmonious, basic, all that relate to something, materials needed, variety, concerning, about (Hayani, 2018; Nurhayati,
2018; Nurlaila et al., 2017). Meurukon, with a prefix meu-, means doing or relating to rukon (harmony). Thus, Meurukon can be interpreted as an activity that deals with harmony or something fundamental, such as prayer principles and pilgrimage principles. However, the meaning of Meurukon in this study is an activity to discuss various religious problems with poetry media between one group and another group (Iskandar et al., 2018; Muhammad, 2019; Nucifera \& Hidayat, 2019). 
This research is important because of the following reasons. First, Meurukon is a learning activity to discuss religious matters between one group and another group in public. Second, Meurukon takes place in an open field or in a place of worship, so that everyone can watch it to gain knowledge. Third, to convey material in Meurukon, poetry or poetic language is used in the form of pantun or nalam (nazam). The use of oral poetry media attracts the audience because, in addition to gaining knowledge, they are also entertained.

Although Meurukon is a means of learning for many people, there is not much academic research in the field. Until now, only three scientific studies of Meurukon have been found. First, the research by which focuses on revitalizing the Meurukon tradition as a local culture in the learning of aqeedah in Muara Batu District, North Aceh District. The results of this study are in the form of a description of the efforts made by the community to revitalize Meurukon activities related to aqeedah learning or theology. Second, Indrayanto (2019) focuses on the case study of the Meurukon tradition in the Gampong Lamgapang community, Krueng Barona Jaya, Aceh Besar District. The results of this study indicate that the performance of Meurukon experienced many obstacles, even though regular exercises and socialization to the youth had been carried out. Another interesting result is that Meurukon is practiced by women, different from other regions where it is practiced by men. Third, the research was conduted by (Mirza \& Aksa, n.d.) on various Acehnese oral traditions as a medium for public education. The results of this study are that many oral traditions in Aceh are used as a medium for public education, one of which is Meurukon. Therefore, Meurukon needs to be preserved and developed (Astuti, 2017; Furqan, 2019).

From the three studies discussed the problem of Meurukon function was only conducted by Mirza and Aksa (2010), however there was none concerning with the structure of Meurukon. Therefore, 'a comprehensive study of the structure and function of Meurukon is important'. The benefits of this research are to provide a theoretical understanding that Meurukon has a systematic structure and functions that are important in socio-cultural life (Asnelida et al., 2017). In addition, practically, the results of this study can be one model of learning in all fields of science such as religious science and other sciences (Erfinawati \& Ismawirna, 2019; Lubis, 2019).

Oral poetry is a traditional form of literary expression widely distributed through the world and is now recognized as one important of human communication (Finnegan, 2018; Foley, 2011). Oral poetry has many types, such as proverb, riddle, lullaby, and others that live in various languages, such as pantun in Malay and hadih maja and Meurukon in Acehnese. Some oral poems are delivered openly in the presence of listeners by poets. There are also those that are staged in groups with the composition of songs, intonation, sounds, and sometimes accompanied by certain instruments. This is in line with the statement of Finnegan (2018) that "Oral poems are more than just texts, for they rely essentially on performance for their realization. The main modes of delivery are the singing, intoning, and spoken voice of one or more performers, sometimes supplemented by instrumental accompaniment (Harris, 2008)."

Oral poetry is often delivered based on the poet's typical style. "The oral formulaic process depends on creation by the performers during the act of performance (Finnegan, 2018). However, oral poetry also has formulas that vary from one language to another. The variety of oral poetry formulas needs to be found out through research. Oral poetry in the manoe pucok tradition in West Aceh (Indaty et al., 2018), for example, has a different formula than the poetry doda idi or lullabies in Aceh Jaya (Andriani et al., 2019) and lullabies in Pidie (Anwar, 2017). On the other hand, oral poetry is different from written poetry, because it is more aggressive (Herman et al., 2019; Herman \& Hamid, 2019; Samad, 
2015). Oral poetry has the color of a thick ethnic culture and a distinctive source of wisdom. Therefore, according to Stanfield (2000), "in weaving an indigenous paradigm, it becomes apparent that phenomena such as time, space, spirituality, and human relationships with nature are culture bound. So are the most fundamental configurations and contents of human communication and interaction in a culture...."According to As (2016), Meurukon is a very Islamic Acehnese art and is used as one of the da'wah strategies in conveying various issues of Islamic law to the community. Two groups involved in Meurukon ask each other questions about Islamic law. Therefore, those who are members of the Meurukon group must truly master the issue of Islamic law in order to be able to answer questions from the other group.

As (2016) also explained that in the initial stages of Meurukon or at the first half of night, the two groups Meurukon ask each other questions that are light and easy to understand in general by the community. However, at the second half of night they start asking each other hard or difficult questions. Sometimes certain Meurukon groups cannot answer questions with theorems (Qur'an and hadith) and aqli arguments (logic or common sense, including ijmak and qiyas). The Meurukon group which is unable to answer more questions from the other group is declared de facto defeated by the audience.

The quality of the questions and answers given by each of the Meurukon groups is assessed openly by the people who are informal judges. To avoid misinterpretation, this event is not referred to as a match or an argument about religion, but is called an act of religions (explaining religious issues) (Mirza \& Aksa, 2010). There has never been other material in Meurukon, except about religion. Therefore, Meurukon is actually the art of rectifying religious problems. If any other discussion is present, it is usually discussed in the preamble section. Meurukon activities are deliberately not mentioned as a race, with the aim of becoming a soothing religious discussion. In addition, there is no such thing as losing and winning, although in some events of Meurukon these days there is a jury that assesses the Meurukon group to be declared a champion, such as in the 2018 Aceh Culture Week event. The cheh term in the Meurukon group is the group leader, while syaikhuna is the honorific for all Meurukon group members. Each group usually consists of 7 members and 1 cheh. Cheh is tasked with starting rukôn simultaneously with his group members, asking questions, answering the other group's questions, and commanding his members to answer simultaneously.

Meurukon as a literary work also plays a role in conveying certain messages. This is because literature often has links with social institutions and has social functions and benefits socially (Budianta, 2014). On the other hand, from a substantial point of view, Meurukon is a medium for teaching religious knowledge. In this connection, Finnegan (2018) says "Oral poetry can also play religious, ceremonial, artistic, and recreational roles for both individuals, and wider groups." The way of learning with poetry media can be referred to as one of the features of the Acehnese people in the field of education. For this reason, Meurukon is included in the aspect of local wisdom. According to Ratna (2003), local wisdom has added value because it is evacuated through the treasures of its own culture as belonging to ancestors. In addition, local wisdom serves to contribute to a wider culture, both at national and international levels. Thus, local wisdom in Meurukon can contribute more broadly in the world of modern learning. Meurukon also functions as solace or as entertainment. In this context, Pudentia (2015) says that solace is something very important in the Malay tradition because it functions as a catharsis that is not less important than tragedy in the western culture. This means that universal aesthetic values are also found in Meurukon as staged poetry. Meurukon is performed at night, starting at around 9:00 pm (after evening prayer) until 4:30 a.m. or before the morning prayer (As, 2016). The audience are able to hold on until the event is over because the intergroup Meurukon discussion takes place interactively 
and openly.

\section{METHOD}

This research uses a qualitative approach. The sources of research data are the Meurukon texts along with the videotapes of the meurukon show at the Aceh Cultural Event (PKA) in 2018. The series of Meurukon shows are all Meurukon stages exhibited by the Meurukon group. The research data are all sequences relating to the structure and function of Meurukon, both from the text and the recording of Meurukon shows. The data of this study were collected by means of recording, reading, and listening. Denzin \& Lincoln (2008) state that recording technique is a visual method that is very urgent and often used by qualitative researchers as a tool for recording and documenting social life. The visual method is also able to bring the researcher directly into the real world. The instrument for recording was camcorder, while reading and listening were carried out by the researchers as key instruments. The data are analyzed qualitatively based on (Priest et al., 2002) views related to the mechanism of text analysis and interaction. The stages of analysis are as follows: (1) reading Meurukon text carefully and deeply,

Assalamualaikom saleuem seujahtra
Keu rakan mandum nyang seu-agama
Mudah-mudahan beuseulamat iman
Bahgia udép donya akhirat
...
Kamoe troh keunoe dalam festival
Geuyue meurukon ngon seni budaya
Nibak PKA ka geu-adakan
Kamoe meudatang ingin beulaja
...
'Ohnoe mumada wallahu'alam
Jinoe hai rakan rukon tabaca
'Ohnoe mumada wallahu'alam
Kamoe meutanyong ubak syaikhuna

After saying the preamble with simultaneous singing, cheh starts asking ....

Meutoh agama seubeunarnya ulon sudi Peugah beumeuri abéh mandum hai syaikhuna Mandum geutanyoe sidroe Tuhan beutaturi Padum boh sipheuet neuci seubut hai syaikhuna
(2) sorting data into Meurukon structure and function section, (3) analyzing data comprehensively, (4) verifying research results with experts and peers, and ( 5) concluding the results of the study.

\section{RESULT AND DISCUSSIONS}

\section{Structure of Meurukon}

The Meurukon structure includes the parts: (a) opening, (b) contents, and (c) closing.

\section{Opening Part}

The opening part consists of greetings and blessings. The greeting words are assalamualaikum warahmatullahi wabarakatuh. Mukaddimah or preface contains praises to Allah, peace be upon the Messenger of Allah and his companions, respect for the clerics, teachers, all members of Meurukon, spectators, and hosts of the organizers. After respect, cheh introduces the origin of the region, customs int their region, and other things about their group. The following is a brief example of the rukon opening for PKA-7.
Assalamualaikom and best wishes

To all brothers and sisters in Islam

Our hope is that our faith is to be safe

Live happily in the world and in the Hereafter

We come here in this festival

To perform Meurukon and art and culture

In this PKA that has been held

We come here in order to learn

'That's all the preamble wallahu'alam

Now we would like to read the rukon

'That's all the preamble wallahu'alam

We would like to ask syaikhuna questions to the other group. Examples are as.

$\cdots$

I am in fact keen on talking about religion

Tell everything important oh syaikhuna

We all have to know the only God

How many attributes of His, please mention it oh syaikhuna 


\section{Content Section}

This section is the main part of Meurukon. Several topics that are mainly discussed in this section include the matters about (a) the word bismillah, (b) specific religion, (c) prayer, (d) water, and (e) faith (aqeedah).

\section{Regarding Bismillah}

This section discusses the word "bismillahirrahmanirrahim", including its setting and use: when it is obligatory, recommended, neutral, disapproved, or forbidden to be read. This topic could take an hour to be discussed..

Su-eue
Bismillahirrahmanirrahim na padum boh h
Jaweueb
Na sikureueng blah boh harah
Phôn harah ba dua harah sin
Keulhèe harah mim wahé syèdara
Nyang keupeuet aléh,keulimong lam
Keunam hai tèelan lam namanya
Keutujôh ha keulapan aléh
Gohlom abéh lôntuwan baca
Keusikureueng lam
Keusiplôh tèelan ra namanya
Keusiblah ha dua blah mim
Keulhèe blah nun hai syèdara
Keupeuet blah aléh keulimong blah lam
Keunam blah tèelan ra namanya
Keutujôh blah ha keulapan blah ya
Sikureueng blah mim ka sampôreuna.

Based on the example above, the question asked is about the total Arabic letters within the word bismillahirrahmanirrahim. The answer is 19 letters, consisting of letters $b a$, sin, mim, alif, lam, lam, ha, alif, lam, ra, ha, mim, nun, alif, lam, ra, ha, ya, mim.

\section{Regarding Specific Religion Issues}

This section examines about Faith, Piety, Religious Teachings and the

Question
How many letters are there in the word
Bismillahirrahmanirrahim?
Answer
There are 19 letters
The first is letter $b a$, the second is sin
The third is letter mim oh my friends
The fourth is alif, the fifth is lam
Six is lam oh my friends
The seventh is $h a$, the eighth is aléh
Not finished yet to read
The ninth is lam
The tenth is called $r a$
The eleventh ha, the twelfth mim
The thirteenth $n u n$ oh my friends
The fourteenth is $a l i f$, the fifteenth lam
The sixteenth called $r a$ my friend
The seventeenth $h a$, the eighteenth ya
The nineteenth mim and all completed

Prophets Teachings. The question contained in this section is getting harder; as a result there are many groups of people who are unable to answer this question. There are also several people who can answer it; however, they cannot put it into a harmonious rhyme lyrics and rhythm. Only a few people can give the perfect answer with the interesting rhythm. The example below is a special case about a good wife based on the religious views.

\begin{tabular}{|l|l|}
\hline $\begin{array}{l}\text { Su-eue } \\
\text { Toh roe sigot-got ureueng inong dalam agama? }\end{array}$ & $\begin{array}{l}\text { Question } \\
\text { Who are the righteous women based on religious view? }\end{array}$ \\
\hline $\begin{array}{l}\text { Jaweueb } \\
\text { Bigot-got ureueng inong neukheun lé Nabi } \\
\text { Beurangkajan han tom masam ngon suami }\end{array}$ & $\begin{array}{l}\text { The righteous wifes according to the Prophets } \\
\text { arethose who never frown upon husband }\end{array}$ \\
$\begin{array}{l}\text { Meunan sabé dalam haté beuthat lam sôsah } \\
\text { Nibak surôhan hantom sagai dijih mubantah }\end{array}$ & $\begin{array}{l}\text { Be that way even though it's hard } \\
\text { Never disobeys every order }\end{array}$ \\
$\begin{array}{l}\text { Sabé dijaga jeueb-jeueb peukara dum kewajiban } \\
\text { Walé meuseuké bandum sinaroe dum penjagaan } \\
\ldots . .\end{array}$ & $\begin{array}{l}\text { Always preserve all obligatory matters } \\
\text { Even though it's difficult, everything is maintained properly } \\
\text {... }\end{array}$ \\
\hline
\end{tabular}




\section{Regarding Prayers}

This section thoroughly discusses about who deserves to be a leader during prayers (imam), what attitude of the congregation who follows the imam (makmum) should be like, the purpose and importance of five-time prayers, the meaning of 13 pillars of prayer, and the power of prayer. The following are examples about the benefits of prayer.

\begin{tabular}{|c|c|}
\hline Su-eue & Question \\
\hline Faedah seumayang na padum peukara? & How many benefits are there in prayer? \\
\hline Jaweueb & Answer \\
\hline Faèdah seumayang na tujôh blah & There are 17 benefits of prayer \\
\hline Neudeungo beusah ulôn bileueng sa & Listen carefully I will count it \\
\hline Pertama phôn beureukat umu & The first is blessing to have age of joy \\
\hline Dua hai teungku beureukat hareuta & The second oh my friend is blessing of wealth \\
\hline Teuma nyang keulhèe mudah raseuki & And then the third is blessing of fortune \\
\hline Keupeuet Tuhan bri cahya ie muka & The fourth is God brightens one's countenance \\
\hline Nyang keulimong neubri trang haté & The fifth is it strengthens the heart \\
\hline Keunam tapiké kong iman gata & The sixth increases one's faith \\
\hline Keutujôh doa Tuhan teurimong & The seventh is that God answers one's dua \\
\hline Geudeungo rijang pue tapinta & He heard everything we've ever asked for \\
\hline Keulapan seunang watèe tasukreuet & The eighth is blessing of a happy death \\
\hline Nyawong jiteubiet mangat lagoina & Life is taken pleasantly \\
\hline Deuek deungon grah masa nyan tan & Hungry and thirsty at that time did not exist \\
\hline Rahmat Tuhan Neubri keu gata & God blessings are given to you \\
\hline Keusikureueng peungeuh lam kubu & The ninth is resting in the place of light \\
\hline Bagoe hai teungku lampujih ka na & As if there are many lamps \\
\hline Nyang keusiplôh rijang geuhisab & The tenth is the deeds are quickly calculated \\
\hline Deungon mangat jawaban gata & You can answer everything very easily \\
\hline Nyang keusiblah 'oh tajôk surat & The eleventh is time to hand in the letter \\
\hline Ngon jaroe uneun han meutuka & The reward and punishment will not be confused \\
\hline Nyang keudua blah Tuhan bri payông & The twelfth God gives shelter \\
\hline Uroe tutông blang padang masya & On the very hot day in padang mahsyar \\
\hline Lhee blah lalu tajak bak titi & The thirteenth is able to walk fast on the bridge God's gift is \\
\hline Karônya Rabbi ban kilat faja & like lightning dawn \\
\hline Nyang keupeuet blah brat timbangan & The fourteenth is the weight balance \\
\hline Watee geutimang amalan gata & When your deeds weighed \\
\hline Padok ngon 'azeueb keulimong blah & Kept you away from torment is the fifteenth \\
\hline Neupeusiblah bak nuraka & Kept you away from the hell \\
\hline Nyang keunam blah beugot neupham & The sixteenth understands it well \\
\hline Keumeunangan tamong syeuruga & Victory entering the heaven \\
\hline Keutujôh blah ulôn peutrang & The seventeenth is God lights you up \\
\hline Takalon Tuhan ngon mata dua & Seeing God with your own eyes \\
\hline Nyan dum faèdah Neubri lé Tuhan & That's all the benefits given by God \\
\hline Pakon hai taulan tasia-sia? & Why we waste it all my friends? \\
\hline
\end{tabular}

\section{Regarding Water}

There are two types of water; the first type is sacred and purifying, while the second category is disapproved and forbidden. The next discussion includes the explanation about two kulah (270 liters) water, how much the volume is, the good deeds toward water, impure water, and other discussions relates to water based on religious perspective. 


\begin{tabular}{|l|l|}
\hline Su-eue & Question \\
\hline $\begin{array}{l}\text { Ie nyang suci menyucikan na padum bagoe } \\
\text { Peugah bak kamoe wahé syaikhuna }\end{array}$ & How many types of sacred and purifying water are? \\
\hline Jaweueb & Please tell us oh Sheikh! \\
\hline Ie nyang suci menyucikan na tujoh bagoe & There are 7 types of sacred and purifying water \\
Peureutama phon ie laot meualon-alon & The first and foremost is sea water \\
Geulumbang jitren meulumba-lumba & The waves are swinging \\
Nyang keudua geukheun ie krueng & The second is river water \\
Ie nyang jiplueng u kuala & It flows to the estuary \\
Teuma nyang keu lhee geukheun ie mbon & And then the third is dew \\
Ie nyang jitren di antara & Coming down from the sky \\
Teuma nyang keupeuet geukheun ie ujeuen & The fourth is rainwater \\
Ie nyang jitren di langet donya & The rain comes from clouds \\
Nyang keulimong geukheun ie mon & The fifth is called well water \\
Jeuet tamanoe uléh gata & You can use it for taking a bath \\
Nyang keunam geukheun ia beuku & The sixth is called frozen water \\
'Oh seu-uem ju hilé rata & Which melts when it gets warm \\
Nyang keutujoh ie mata ie & The seventh is spring water \\
Di dalam bumi sinan keulua & It is from near surface of the earth \\
Miseue ie jok dengon ie teubee & Like palm wine water and sugarcane water \\
Adak siribèe kulah jihna & Even though there are thousands of kulah \\
Hana suci menyucikan wahé syedara & It is still impure oh my friends \\
\hline
\end{tabular}

\section{Reagarding Faith (Aqeedah)}

In this section we discuss the issue of monotheism in the form of who God is, the nature of God, the nature of the prophet, and other things related to i'tikad and aqeedah. The following is an example of the demons' issue from the faith perspective.

Su-eue
Wahé syaikhuna hai teungku malém
Pajan masa jén tamong Iseulam
Firman Tuhan teungku neu-iréng
Dan maséng-maséng pakriban macam
Jaweueb
Saboh teumpat dilee lon peugah
Saboh daerah nanjih Nasihin
Dalam jajahan Nanggroe Yaman
Yôh masa nyan Saidil Mursalin
Saboh masa Nabi beurangkat
Ka meusapat deungon bangsa jén
Nabi neuwoe u Nanggroe Mekah
Zaidin Haratah sajan meu-iréng
Saboh gampong Yathfu Nazlah
Meunan geupeugah le ureueng malém
Antara Thaif deungon Mekah
Di sinan piyoh Nabi deungon jén
Nabi di sinan seumayang malam
Jén na sajan di geuniréng
Nabi neubaca ayat Alquran
Keudengaran lé rombongan jén
Tertarék haté dum sigala
Jén that suka meunan lazém
Jén nyan mandum kepala rakyat
Nibak teumpat maséng-maséng

\section{Question}

Oh, dear Sheikh

When do demons embrace Islam?

Gives us the word of God

Each is adjusted

Answer
I tell you one place first
There is one area called Nasihin
Located within the territory of Yemen
On Saidil Mursalin's era
One day when the prophet about to go
To gather with the demons
The Prophet returned to the land of Mecca
Zaidin Haratah joined him together
A village called Nazlah Yathfu
That's what the pious person said
Between Thaif and Mecca
There the Prophet rested with the demons
That's where the Prophet prayed at night
The demons stand alongside him
The Prophet recited the Qur'an
Heard by the demons' group
Their hearts were all interested
Demons really likes it
All of the demons are the heads of its people
In their respective villages




\begin{tabular}{|c|c|}
\hline Nabi deungon jén lheueh nyan berpisah & The Prophet with the demons then separated \\
\hline Neujak u Mekah sinan tinggai jén & Return to Mecca and leave the demons \\
\hline Jen' 'oh watee troh u teumpat & When the demons arrived at their villages \\
\hline Jimeuhei rakyat dum maséng-maséng & They are calling their respective people \\
\hline Dum sigala bri ajaran & All were taught \\
\hline Keubeunaran Muhammad Amin & The truth of Muhammad Amin \\
\hline Mandum geutanyoe tamong Iseulam & All of us convert to Islam \\
\hline Keuputusan meunan jirundéng & That's the decision after negotiating \\
\hline Teuma beudoh bak laén uroe & They all go on another day \\
\hline Tujôh plôh droe bilangan jén & Seventy demons \\
\hline Jak meuteumeung $u$ Nanggroe Mekah & Want to meet in the land of Mecca \\
\hline Dijak peugah maséng-maséng & Want to report individually \\
\hline Kamoe mandum tamong Iseulam & We all embrace Islam \\
\hline Keusucian lahér batén & Inner and outer sanctity \\
\hline Meunan teuseubôt lam Surat Al Ahqaf & That's all said in the letter $\mathrm{Al}$ Ahqaf \\
\hline Ayat Allah meu-iréng-iréng & Allah's verses are rhythmically \\
\hline
\end{tabular}

\section{Closing Section}

This section is usually closed with a prayer led by the host and they also give thanks and ask for apologies from the Meurukon group. The example of a thanking and apologizing is presented as follows.

\begin{abstract}
Rukon ka abéh waréh lonsayang
Kamoe jak riwang keudéh u nanggroe

Meunyo na teupeh meu-ah beureujang

Bek jeuet keu utang 'oh uroe dudoe

Keu nyang po teumpat deungo beutimang Syeuruga manyang Allah bri sampoe

Leupah meukeunong droeneuh peutimang

Kamoe that seunang jroh that neupakoe

Assalamualaikom kamoe ucapkan

Seulamat tinggai kamoe meujak woe
\end{abstract}

\section{Meurukon Functions}

Meurukon has many functions: (1) as a means of religious teachings, (2) as a means of entertainment, and (3) as an interactive-dialogical learning model.

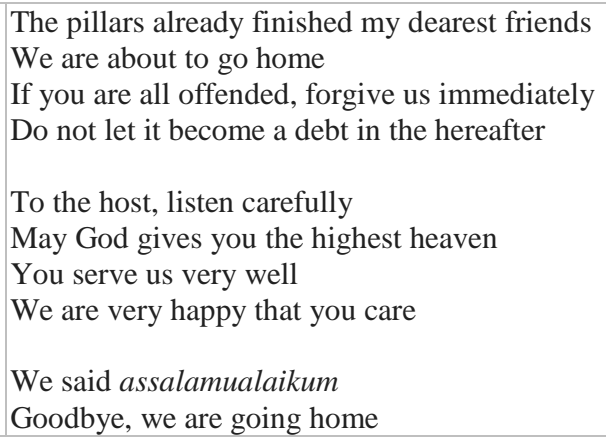

\section{Meurukon as Means of Religious Teachings}

Meurukon functions as a means of religious teachings, especially Islam. All things discussed in Meurukon are related to religion. The following is an example of the law of drinking liquor or wine.

\begin{tabular}{|c|c|}
\hline Su-eue & Question \\
\hline $\begin{array}{l}\text { Siberangkasoe dijéb arak walaupun sigo } \\
\text { Pakriban hukom neupuphom wahé syaikhuna }\end{array}$ & $\begin{array}{l}\text { Those who drink wine although only once } \\
\text { How is the law oh Sheikh? Please explain to us }\end{array}$ \\
\hline Jaweueb & Answer \\
\hline Siberangkasoe dijéb arak walau sikali & Those who drink wine although only once \\
\hline Bateue amai tujoh uroe wahé akhi & Will lost the rewards of 7 days oh my dear friends \\
\hline $\begin{array}{l}\text { Meunyo mabok bateue amai hé syedara } \\
\text { Peuet ploh uroe malaikat teuntèe han teuka } \\
\text { Meunyo lam } 44 \text { uroe nyan hai syaikhuna } \\
\text { Hana jitaubat, maté maksiet kheun Saidina }\end{array}$ & $\begin{array}{l}\text { If you are drunk, you lost all of the good deeds } \\
\text { The angel will not come for } 44 \text { days } \\
\text { If on } 44 \text { days all my dear friends } \\
\text { You do not repent; you will perish immorally }\end{array}$ \\
\hline
\end{tabular}


The type of poem about drinking law above is called nazam, or Aceh poetry consisting of 12 buhu (one line consists of twelve syllables). This poem is specifically about the issue of Islam.

\section{Meurukon as Means of Entertainment}

Meurukon has an entertainment function and it is free. The Meurukon's venue is deliberately chosen in an open field or in the Meunasah. Each group occupies an open shell (hall, cottage) that is near to another cottage group and it is done with face to face. In the opening, each group introduces itself casually, rhythmic, and using humorous languages. This is deliberately done to attract the attention of audiences surrounding the Meurukon arena. Furthermore, The Sheikh continued the questioning and answering session of religious problems with a rhythmic, beautiful, high-pitched song that breaks the silence of the night. The songs commonly used are to express culture and verbal performance (Baron \& Cara, 2003). Usually, all Meurukon members are expert on playing rhythmic languages to help the Sheikh. Sometimes those who ask and answer are the Sheikh, whereas other times it is done all at once by all group members.

In Meurukon, the more solid buhu and pakhok or rhyme and rhythm is delivered, the more pleasant audiences to enjoy it. In other words, the beauty of Meurukon lies in the simultaneous and unified voice between each group member. Moreover, once in a while there is a rather difficult problem in the language of humor that is funny and agile, although a little rough. The famous Meurukon group is often able to amaze the audiences with varied rukon songs. Thus, the audiences can stay longer until the dawn call to do a prayer. To make the opponent's group thinking critically, curiously as well as entertaining the audiences, questions are often asked in the form of puzzles, such as the following example.

\begin{tabular}{l|l|}
\begin{tabular}{l|l|} 
Na sidroe ureueng geu-éh uroe & There is someone who is taking a nap \\
Geumeulumpoe geumeuzina & He is dreaming of having an intercourse \\
Jaga nibak nyan geujak manoe & As soon as it happens, he goes to take a shower \\
$\begin{array}{l}\text { Geujak u mon hana tima } \\
\text { Tima na lam meuseujid }\end{array}$ & Heading to the well but no bucket is available \\
Kiban geuniet geucok tima? & The bucket turns out inside the mosque \\
& What intention does that person should have to take the \\
bucket inside the mosque?
\end{tabular} \\
\hline
\end{tabular}

In Islamic law, a person who has intercourse (whether sperm produced or not) is obliged to take a janabah bath, which is bathing to wash all parts of the body with the intention of cleaning a major impurity since he or she is considered being impure after the sperm is produced either due to sexual intercourse or due to dream. On the other hand, someone who is impure is not allowed to enter the mosque. This issue is brought in the Meurukon by asking how someone who is impure and wants to take a bath takes the bucket inside the mosque. Other group members have to think fast and precisely: does the man really have intercourse in his dreams?

\section{Meurukon as a Learning Model}

Meurukon also functions as an interactive and dialogical learning model. This is due to the whole series of Meurukon takes place in the form of a prominent discussion to explain the various problems, from the ordinary problems to the complicated one. Although throughout the discussion, the Sheikh plays an important role, but all group members also have the opportunity to answer the questions. Every now and then, all group members respond simultaneously with rhythmic language. Simultaneous answers are usually done to answer questions that are commonly 
encountered in Meurukon, because they have already memorized the answers.

The interactive and dialogical learning model in Meurukon does not require the moderator and jury. The moderator unites within the group. While the judges are the entire audiences, it includes both common audiences and educated audiences. The audiences will give applause to a group that can deliver the rukon interestingly and the answer hits the point. Indirectly, the audiences already pinpoint a group that appears to be more attractive and gives the right answer. On the other hand, in the meurukon activities in PKA 2018, the jury system has been introduced. However, in meurukon base villages such as Pidie, Bireuen, and North Aceh there is still no jury in Meurukon.

The absence of formal and de facto juries in Meurukon shows that it provides an open space for ijtihad or dissent between groups. After the Meurukon activity is finished, each group conducts introspection about their performance. If there is a wrong answer, they will seek out the variety of postulates, logic, and if they are not feeling unite, they will learn to achieve team cohesiveness.

\section{CONCLUSION AND RECOMMENDATION}

The conclusions of this study are as follows. Firstly, the Meurukon structure includes the opening section consisting of the opening greetings and mukaddimah 'preface' from each of the meurukon group; the content section discussing in details and thoroughly any Islamic religious matters which include bismillah, problems with prayer, water problems, and problems of faith (aqeedah), and the closing section concerning asking for apology, along with making a $d o^{\prime} a$ or pray, to the opponent group. Secondly, Meurukon has the functions as an entertainment, as a medium of learning religious issues, and a dialogic-interactive learning model in studying religious matters.

\section{REFERENCES}

Andriani, R., Harun, M., \& Fitriani, S. S. (2019). Character value of responsibility in Doda Idi lyrics of Aceh Jaya. International Conference on Early Childhood Education, 130-136.

Anwar, H. (2017). The social culture context and the function of dodaidiâ€ aceh lullaby. ARICIS PROCEEDINGS, 1 .

As, N. B. (2016). Warisan Kesenian Aceh. Aceh Multivision.

Asnelida, C., Yusuf, Y., \& Armia, A. (2017). Tradisi lisan Aceh di kecamatan manggeng kabupaten Aceh Barat Daya. JIM Pendididikan Bahasa Dan Sastra Indonesia, 2(3), 326-337.

Astuti, S. (2017). Agama, Budaya dan Perubahan Sosial Perspektif Pendidikan Islam di Aceh. Jurnal MUDARRISUNA: Media Kajian Pendidikan Agama Islam, 7(1), 2346.

Baron, R., \& Cara, A. C. (2003). Introduction: Creolization and Folklore-Cultural Creativity in Process. Journal of American Folklore, 116(459), 4-8.

Budianta, M. (2014). Teori Kesusastraan. Jakarta: Gramedia Pustaka Utama.

Denzin, N. K., \& Lincoln, Y. S. (2008). Introduction: The discipline and practice of qualitative research.

Erfinawati, E., \& Ismawirna, I. (2019). Nilai budaya dalam sastra lisan 
masyarakat Aceh Jaya. Jurnal Bahasa Dan Sastra, 13(2), 81-89.

Finnegan, R. (2018). Oral poetry: Its nature, significance and social context. Wipf and Stock Publishers.

Foley, J. M. (2011). Oral tradition and its implications. In A new companion to Homer (pp. 146-173). Brill.

Furqan, T. N. (2019). Pelestarian Seni Tutur Di Aceh Ditinjau Dari Perspektif Teori Kebijakan Publik (Studi di Balai Pelestarian Nilai Budaya Aceh). Jurnal Ilmiah Mahasiswa Fakultas Ilmu Sosial \& Ilmu Politik, 4(4).

Harris, J. (2008). Eddic poetry as oral poetry: The evidence of parallel passages in the Helgi poems for questions of composition and performance. Cornell University Library.

Hayani, A. (2018). Analisis Kritis Teks Syair Meurukôn dalam Perspektif Pendidikan Islam. Prosiding Konferensi Integrasi Interkoneksi Islam Dan Sains, 1(1), 69-76.

Herman, R. N., \& Hamid, M. A. (2019). Identity education as the concept of Acehnese character education through nursery rhymes. Proceeding of The International Conference on Literature, 1(1), 227-235.

Herman, R. N., Mukhlis, M., Saiful, S., \& Sanusi, S. (2019). The concepts of prayer and respect as character education of Acehnese children. International Conference on Early Childhood Education, 450-456.

Indaty, N., Harun, M., \& Subhayni, S. (2018). Analisis struktur lahir dan fungsi puisi lisan pada tradisi manoe pucôk. JIM Pendididikan
Bahasa Dan Sastra Indonesia, 3(3), 264-272.

Indrayanto, D. (2019). Semantic equivalence in the subtitling of the post movie into Indonesian $[\mathrm{PhD}$ Thesis]. UNNES.

Iskandar, D., Pujiono, M., \& Samad, I. A. (2018). The Profile of Acehnese Variation: Sociolinguistic Analysis. International Journal of Comparative Literature and Translation Studies, 6(3), 12-19.

Lubis, T. (2019). Tradisi Lisan Nandong Simeulue: Pendekatan Antropolinguistik.

Mirza, F., \& Aksa, M. S. (n.d.). Seni Tradisi Lisan Aceh Sebagai Media Pendidikan Rakyat.

Muhammad, I. (2019). Tradisi literasi Islam dan budaya baca masyarakat Aceh. jurnal mudarrisuna: Media Kajian Pendidikan Agama Islam, 9(1), 251-264.

Nucifera, P., \& Hidayat, M. T. (2019). AN analysis of local wisdom within media literacy. Proceeding of The International Conference on Literature, 1(1), 781-788.

Nurhayati, N. (2018). Meurukôn sebagai media pembelajaran pendidikan agama Islam pada masyarakat Aceh. ITQAN: Jurnal Ilmu-Ilmu Kependidikan, 9(2), 127-142.

Nurlaila, S. L., Sinar, T. S., \& Muchtar, M. (2017). Semantics Equivalence of Cultural Terms of Meurukon Texts Translated from Acehnese into Indonesian'. Proceedings of MICoMS, 373-379.

Priest, H., Roberts, P., \& Woods, L. (2002). An overview of three different approaches to the 
114 | Volume 27, Number 1, February, 2020, Page 103-114

interpretation of qualitative data. Part 1: Theoretical issues.

Pudentia, M. (2015). Metodologi kajian tradisi lisan (edisi revisi). Yayasan Pustaka Obor Indonesia.

Ratna, N. K. (2003). Paradigma sosiologi sastra. Pustaka Pelajar.

Samad, S. A. A. (2015). Character Education Base on Local Wisdom in Aceh (Study on Tradition of Children Education in Aceh Community). Al-Ulum, 15(2), 351370.

Stanfield, J. H. (2000). II.(1994). Ethnic modeling in qualitative research. Handbook of Qualitative Research, 175-188. 